\title{
China's ODI Motivations, Political Risk, Institutional Distance and Location Choice
}

\author{
Jing Han', Xiaoyuan Chu', ${ }^{1}$ e Li² \\ ${ }^{1}$ School of Economics and Resource Management, Beijing Normal University, Beijing, China \\ ${ }^{2}$ PKU Founder Commodities Group Co., Ltd., Beijing, China \\ Email: seancxy@126.com
}

Received 30 May 2014; revised 29 June 2014; accepted 26 July 2014

Copyright (C) 2014 by authors and Scientific Research Publishing Inc.

This work is licensed under the Creative Commons Attribution International License (CC BY). http://creativecommons.org/licenses/by/4.0/

(c) (i) Open Access

\begin{abstract}
Utilizing an outward foreign direct investment (ODI) data sample of 48 countries and districts from the year 2003 to 2010 , and based on institutional distance theory, a resource-based view, an institutional-based view and political risk management theory, this paper applies multiple regression equations to explore the linkages between China's ODI motivations, political risk, institutional distance and location choice. We obtain the following conclusions: 1) there are three different motivations affecting China's ODI location choice, namely, resource-seeking, strategic asset-seeking and market-seeking motivations; 2) generally, China's multinational enterprises are inclined to invest ODI in countries with high political risk and short institutional distance; and 3) multinational enterprises with different ODI motivations have diverse location choices. For resource-seeking foreign investment, Chinese multinational enterprises tend to invest in countries with high political risk and short institutional distance. For strategic asset-seeking foreign investment, Chinese multinational enterprises tend to avoid countries with high political risk and short institutional distance. For market-seeking foreign investment, multinational enterprises of China tend to avoid countries with high political risk and short institutional distance.
\end{abstract}

\section{Keywords}

Outward Foreign Direct Investment, Location Choice, Investment Motivation, Political Risk, Institutional Distance

\section{Introduction}

China is a developing country with an emerging economy, and its outward foreign direct investment (ODI) preferences and behaviors have been the subject of research. In recent years, China's outward foreign direct in- 
vestment shows a trend of accelerated development. By the end of 2012, the value of China's foreign direct investment ranked third worldwide and first among developing countries. However, while Chinese multinational enterprises (MNEs) engaging in ODI are making prominent achievements, they are suffering from the significant political risks of host countries. This study explores how political risk affects ODI made by Chinese MNEs and is of great practical significance. In contrast to the rapid development of ODI in emerging economies, traditional ODI theory for developed and developing countries progresses slowly and may not suitably explain the level of ODI from emerging economies. China is a major emerging economies. And in the course of its rapid ODI development, China's ODI shows many features that traditional theory cannot explain. One example is that traditional ODI theory emphasizes that MNEs could be internationalized under the conditions of their own competitive advantages. However, Chinese MNEs actively invest abroad with great success without ODI advantages. Another example is that the effects caused by host-country institutional factors for China's ODI MNEs are inconsistent with the expectations of traditional theories. Compared with the ODI of developed countries, China’s ODI shows preferences for high political risk in location choice.

\section{Literature Review}

Location choice, an important strategic decision for ODI, determines the success and risk of a firm's investment [1]. Research on ODI in China has developed under institution-based theory [2], resource-based theory [3] and their derived theory: the eclectic theory of international production [4]. However, it is difficult to reconcile these theories when examining China's ODI because these theories ignore the fact that external factors pertaining to the firm engaging in ODI exert a direct or indirect impact on ODI. Therefore, we need to utilize more sophisticated theories to reveal the mechanism of the impact of institutional factors and resources factors (ODI motivations) on China's ODI. Thus, to improve existing ODI theory, this paper builds a new theoretical analysis system and establishes an integrated research framework, the host-country resources and institutional factors, to analyze the ODI location choice for MNEs from emerging economies.

It can be useful to explain the behaviors of foreign direct investment in developing countries from an institutional distance perspective [5] [6]. In addition, the use of this method to study the ODI phenomenon in developing countries is widely accepted. There has been significant research studying MNEs' internationalization strategies and ODI performances, such as studies concerning location choice [7], business models [8], management strategy [9], and M\&A performance analysis [10]. However, there is still an academic gap in the analysis of location choice and ODI motivation. This gap is research that considers institutional distance. Currently, outward foreign direct investment MNEs have been significantly influenced and restricted by institutional distance and ODI motivation. Hence, the study of China's ODI institutional distance and ODI motivation helps to develop and complete institutional distance theory.

Political risk is another important factor for ODI location choice [11]. Schneider's research finds that political instability significantly reduces the inflow of foreign direct investment [12]. Matthias finds that government stability, internal and external conflict, corruption and ethnic tensions, law and order, democratic accountability of government, and quality of bureaucracy are highly significant determinants of foreign investment inflows [13]. All of these researches were performed using the ODI of developed countries. Whether the same conclusion can be applied to the ODI of China is unclear.

According to prior research, the exchange rate has some effect on foreign direct investment [14]. In the long run, openness contributes positively to the inflow of foreign direct investment (FDI) in developing economies [15]. Some interrelationships between geographic distance and FDI have been found [16]. Improving domestic infrastructure helps increase the inflow of FDI, and there is a significant relationship between economic risks and foreign direct investment [17]. Firms' motivations have a significant impact on the choice of their investment locations [18]. Reduced levels of political risk are associated with an increase in FDI inflows [19]. Among Finnish MNEs, High informal institutional distance results in a preference for greenfield investments, and high formal institutional distance results in a preference for acquisitions [20].

Most of the existing research assumes that either motivation of ODI or institutional factors between China and host countries are homogeneous, which ignores the different ODI effects caused by target resources or institutional factors. To facilitate a better understanding of how the resources factors and institutional factors jointly affect China's ODI, this paper decomposes the above two factors (institution factors include institutional distance and political risk; resources factors include natural resources motivation, strategic asset motivation, and 
market motivation) and studies the ODI location choice affected by the resources factors and institutional factors simultaneously. In this study, we establish an analytical framework for China's foreign direct investment motivation, political risk, institutional distance and ODI location choice to analyze their relationships within the context of China's ODI.

We hypothesize the following:

First, both institutional factors and resources factors have some effect on the local choice of China's ODI.

Second, there are some interactions between institutional factors and resources factors with regards to ODI.

$$
\mathrm{ODI}=\beta_{0}+\sum \lambda_{1} I F+\sum \lambda_{2} R F+\sum \lambda_{3} I F \times R F
$$

where IF is short for institutional factors, RF is short for resources factors.

\section{Data and Methodology}

According to the principle of availability and consistency of data, this paper selects forty-eight countries and districts as a sample of host countries for China's ODI, which that represents a huge amount of China's ODI. The forty-eight countries and districts are as follows: Austria, Switzerland, Australia, Mexico, Belgium, Poland, Denmark, Germany, France, Finland, Korea, the Netherlands, Canada, Czech Republic, Romania, the United States, Norway, Japan, Sweden, Turkey, Spain, Greece, New Zealand, Hungary, Israel, Italy, the United Kingdom, Chile, Morocco, Argentina, Pakistan, Brazil, Russia, Ecuador, the Philippines, Colombia, Malaysia, Peru, South Africa, Saudi Arabia, Thailand, Singapore, Iran, India, Indonesia, Jordan, Hong Kong, and Vietnam. This paper uses different sources to avoid deviations due to single data source. The definitions of variables and data sources are shown in Table 1.

\subsection{Multiple Regression Equation Model}

To test the hypotheses, this paper suggests the following multiple regression equation:

$$
\mathrm{ODI}_{i t}=\beta_{0}+\sum \lambda_{1} \mathrm{MOT}_{i t}+\sum \lambda_{2} C V_{i t}+\varepsilon_{i t} .
$$

\begin{tabular}{|c|c|c|c|}
\hline & Variable & Operational Definition or Proxy Variable & Data source \\
\hline Explained variables & Location Choice & $\begin{array}{l}\text { ODI: The stock amount of China's } \\
\text { ODI in host countries }\end{array}$ & $\begin{array}{l}2010 \text { Statistical Bulletin of China’s } \\
\text { Outward Foreign Direct Investment }\end{array}$ \\
\hline \multirow{6}{*}{ Control variables (CV) } & Exchange Rate & $\begin{array}{l}\text { Exch: The host-country’s official annual } \\
\text { average exchange rate against RMB }\end{array}$ & World Bank Development Indicator \\
\hline & Attitude on ODI & Op: Openness to ODI & UNCTAD ODI database \\
\hline & Geographic Distance & $\begin{array}{l}\text { Dis: The geographic distance between } \\
\text { the host and home countries }\end{array}$ & http://www.cepii.fr/welcome.asp \\
\hline & Infrastructure Construction & $\begin{array}{l}\text { Mob: The number of fixed-telephones } \\
\text { in the host-country }\end{array}$ & World Bank Development Indicator \\
\hline & Economic Risk & Inf: The host-country’s inflation rate & World Economic Outlook Database \\
\hline & Cluster & Reg: Dummy variable & World Economic Outlook Database \\
\hline \multirow{3}{*}{$\begin{array}{l}\text { Explanatory variables } \\
\text { Resources factors } \\
\text { (Types of motivation, } \\
\text { MOT for short) }\end{array}$} & ResourceSeeking Motivation & $\begin{array}{l}\text { Ore: the ratio of the host country's ore } \\
\text { and metal exports to its merchandise } \\
\text { exports }\end{array}$ & World Bank Development Indicator \\
\hline & Strategic Asset Motivation & $\begin{array}{l}\text { Pat: The host country's total (resident } \\
\text { plus non-resident) annual patent } \\
\text { registrations }\end{array}$ & World Bank Development Indicator \\
\hline & Market Seeking Motivation & Gdp: The host-country’s GDP & World Bank Development Indicator \\
\hline \multirow{2}{*}{$\begin{array}{l}\text { Moderating variables } \\
\text { Institutional factors }\end{array}$} & Political Risk & $\begin{array}{l}\text { Pr: The host country’s political risk } \\
\text { indicator }\end{array}$ & International Country Risk Guide (ICRG) \\
\hline & Institutional Distance & $\begin{array}{l}\text { Id: The institutional distance between } \\
\text { the host and home countries }\end{array}$ & World Bank Development Indicator \\
\hline
\end{tabular}

Table 1. Definitions of variables and data sources. 


$$
\begin{aligned}
& \mathrm{ODI}_{i t}=\beta_{0}+\beta_{1} I_{i t}+\sum \lambda_{1} \mathrm{MOT}_{i t}+\sum \lambda_{2} C V_{i t}+\varepsilon_{i t} . \\
& \mathrm{ODI}_{i t}=\beta_{0}+\beta_{1} \mathrm{Pr}_{i t}+\sum \lambda_{1} \mathrm{MOT}_{i t}+\sum \lambda_{2} C V_{i t}+\varepsilon_{i t} . \\
& \mathrm{ODI}_{i t}=\beta_{0}+\beta_{1} \mathrm{Pr}_{i t}+\beta_{2} I d_{i t}+\sum \lambda_{1} \mathrm{MOT}_{i t}+\sum \lambda_{2} C V_{i t}+\varepsilon_{i t} . \\
& \mathrm{ODI}_{i t}=\beta_{0}+\beta_{1} I d_{i t}+\beta_{2} \mathrm{MOT}_{i t}+\beta_{3}\left(\mathrm{MOT}_{i t} \times I d_{i t}\right)+\sum \lambda_{1} \mathrm{MOT}_{i t}+\sum \lambda_{2} C V_{i t}+\varepsilon_{i t} . \\
& \mathrm{ODI}_{i t}=\beta_{0}+\beta_{1} \mathrm{Pr}_{i t}+\beta_{2} \mathrm{MOT}_{i t}+\beta_{3}\left(\mathrm{MOT}_{i t} \times P r_{i t}\right)+\sum \lambda_{1} \mathrm{MOT}_{i t}+\sum \lambda_{2} C V_{i t}+\varepsilon_{i t} . \\
& \mathrm{ODI}_{i t}=\beta_{0}+\beta_{1} I_{i t}+\beta_{2} \mathrm{MOT}_{i t}+\beta_{3}\left(\mathrm{MOT}_{i t} \times I d_{i t}\right)+\beta_{4} \operatorname{Pr}_{i t}+\beta_{5}\left(\mathrm{MOT}_{i t} \times P r_{i t}\right)+\sum \lambda_{1} \mathrm{MOT}_{i t}+\sum \lambda_{2} C V_{i t}+\varepsilon_{i t} .
\end{aligned}
$$

where ODI denotes the stock amount of China's ODI in host countries; MOT denotes the types of motivation of China's ODI; CV denotes control variables, including Exch, Op, Mob, Dis, and Inf; $i$ denotes country; $t$ denotes time; and $\varepsilon$ is an error term. The data are transformed into natural logarithms as we expect nonlinearities in the relationships based on the theory and previous empirical work.

Using panel data, we employ Eviews 6.0 to make the estimation regression of all variables. The descriptive statistics and correlation matrix of variables are shown in Table 2. All correlations are low, and the variance inflation factors (VIF), also shown in Table 2, are well below the acceptable level of 10, showing no serious problems of multicollinearity.

\subsection{Estimation Results}

\begin{tabular}{|c|c|c|c|c|c|c|c|c|c|c|c|c|}
\hline Variable & 1 & 2 & 3 & 4 & 5 & 6 & 7 & 8 & 9 & 10 & 11 & 12 \\
\hline $1 \operatorname{lnODI}$ & 1 & & & & & & & & & & & \\
\hline 2 Op & 0.056 & 1 & & & & & & & & & & \\
\hline 3 Ore & 0.056 & 0.241 & 1 & & & & & & & & & \\
\hline $4 \mathrm{Inf}$ & -0.044 & 0.082 & 0.082 & 1 & & & & & & & & \\
\hline 5 Reg & -0.071 & 0.271 & 0.271 & -0.099 & 1 & & & & & & & \\
\hline $6 \operatorname{lnGdp}$ & 0.345 & -0.15 & -0.15 & -0.228 & 0.219 & 1 & & & & & & \\
\hline $7 \ln P a t$ & 0.225 & -0.216 & -0.216 & -0.226 & 0.13 & 0.84 & 1 & & & & & \\
\hline $8 \ln \mathrm{Pr}$ & 0.068 & 0.035 & 0.035 & 0.415 & -0.381 & -0.249 & -0.387 & 1 & & & & \\
\hline $9 \operatorname{lnMob}$ & 0.179 & -0.048 & -0.048 & -0.332 & 0.187 & 0.251 & 0.237 & -0.439 & 1 & & & \\
\hline $10 \operatorname{lnDis}$ & -0.294 & 0.392 & 0.392 & 0.132 & 0.686 & -0.051 & -0.233 & -0.011 & 0.056 & 1 & & \\
\hline $11 \operatorname{lnExch}$ & 0.125 & 0.055 & 0.055 & 0.292 & -0.367 & -0.206 & -0.105 & 0.403 & -0.407 & -0.375 & 1 & \\
\hline $12 \operatorname{lnId}$ & 0.113 & 0.094 & 0.094 & -0.548 & 0.241 & 0.192 & 0.254 & -0.615 & 0.414 & -0.016 & -0.299 & 1 \\
\hline Minimum & 1.946 & 0.084 & 0.001 & -0.219 & 1 & 9.23 & 1.386 & 1.846 & 0.693 & 6.863 & -0.694 & -2.303 \\
\hline Maximum & 16.807 & 1.930 & 0.648 & 0.24 & 6 & 16.496 & 12.817 & 4.02 & 5.278 & 9.867 & 9.832 & 3.664 \\
\hline Mean & 8.878 & 0.383 & 0.068 & 0.049 & 2.646 & 12.786 & 7.189 & 3.155 & 4.295 & 8.858 & 2.161 & 2.266 \\
\hline VIN & & 1.338 & 1.583 & 1.597 & 2.833 & 4.158 & 4.692 & 2.445 & 1.432 & 3.213 & 1.761 & 2.06 \\
\hline
\end{tabular}

We use the above-mentioned multiple regression equations to analyze the effects of China's ODI motivations, political risk and institutional distance on location choices, as shown in Tables 3-5.

As shown in the tables below, we obtain several findings. First, China's ODI MNEs tend to invest in countries with high political risk. Second, China's ODI MNEs tend to invest in countries with short institutional distances.

\section{Table 2. Correlation matrix of variables and VIF test.}


Table 3. China’s ODI motivations and location choice (explained variable: ODI).

\begin{tabular}{|c|c|c|c|c|c|}
\hline Variable & Model 1 & Model 2 & Model 3 & Model 4 & Model 5 \\
\hline \multicolumn{6}{|l|}{ Motivations } \\
\hline \multirow[t]{2}{*}{ Ore } & & $2.361^{* * *}$ & & & $4.971^{* * *}$ \\
\hline & & (4.533) & & & (5.281) \\
\hline \multirow[t]{2}{*}{ Pat } & & & $0.198^{* * *}$ & & $0.432^{* * *}$ \\
\hline & & & (3.462) & & $(4.735)$ \\
\hline \multirow[t]{2}{*}{ Gdp } & & & & $0.787^{* * *}$ & $1.595^{* * *}$ \\
\hline & & & & (3.652) & (11.144) \\
\hline \multicolumn{6}{|c|}{ Control variables } \\
\hline \multirow[t]{2}{*}{ Mob } & $0.686^{* * *}$ & 0.146 & -0.001 & -0.182 & $0.342^{* *}$ \\
\hline & $(0.190)$ & (0.954) & $(-0.004)$ & $(-1.279)$ & (2.099) \\
\hline \multirow[t]{2}{*}{ Op } & $1.647^{* * *}$ & -0.006 & $0.716^{*}$ & $1.646^{* * *}$ & $3.325^{* * *}$ \\
\hline & $(0.410)$ & $(-0.019)$ & (1.875) & (4.813) & (8.378) \\
\hline \multirow[t]{2}{*}{ Dis } & $-1.533^{* * *}$ & $-0.711^{* * *}$ & -0.010 & 0.303 & $-1.418^{* * *}$ \\
\hline & $(0.283)$ & $(-2.929)$ & $(-0.038)$ & (1.360) & $(-4.952)$ \\
\hline \multirow[t]{2}{*}{ Exch } & $0.133^{* * *}$ & -0.010 & 0.039 & $0.087^{* *}$ & $0.171^{* * *}$ \\
\hline & $(0.051)$ & $(-0.243)$ & (0.939) & (2.288) & (3.861) \\
\hline \multirow[t]{2}{*}{ Inf } & $4.629^{* * *}$ & $5.019^{* * *}$ & $5.367^{* * *}$ & $6.812^{* * *}$ & $7.957^{* * *}$ \\
\hline & $(2.492)$ & (2.489) & $(2.674)$ & (3.722) & (3.829) \\
\hline \multirow[t]{2}{*}{ Reg } & $0.523^{* * *}$ & $-0.430^{* * *}$ & $-0.521^{* * *}$ & $-0.601^{* * *}$ & $0.355^{* * *}$ \\
\hline & $(0.121)$ & $(-4.408)$ & $(-5.154)$ & $(-6.678)$ & (3.398) \\
\hline$R^{2}$ & 0.198 & 0.404 & 0.216 & 0.352 & 0.455 \\
\hline Adjusted $R^{2}$ & 0.185 & 0.391 & 0.201 & 0.341 & 0.442 \\
\hline$N$ & 384 & 384 & 384 & 384 & 384 \\
\hline
\end{tabular}

$* * *$, ** and $*$ indicate that the coefficient is significant at the $0.01,0.05$ and 0.1 levels, respectively.

Table 4. Political risk, institutional distance and China’s ODI location choice (explained variable: ODI).

\begin{tabular}{|c|c|c|c|}
\hline Variable & Model 1 & Model 2 & Model 3 \\
\hline \multirow[t]{2}{*}{$\operatorname{Pr}$} & $1.423^{* * *}$ & & $1.481^{* * *}$ \\
\hline & $(5.078)$ & & (4.933) \\
\hline \multirow[t]{2}{*}{ Id } & & $-0.155^{* *}$ & $-0.071^{* *}$ \\
\hline & & $(-2.265)$ & $(-2.345)$ \\
\hline \multirow[t]{2}{*}{ Ore } & $5.243^{* * *}$ & $5.241^{* * *}$ & $5.133^{* * *}$ \\
\hline & $(5.741)$ & $(5.434)$ & $(5.484)$ \\
\hline \multirow[t]{2}{*}{ Pat } & $0.255^{* * *}$ & $0.404^{* * *}$ & $0.26^{* * *}$ \\
\hline & $(2.687)$ & $(4.312)$ & (2.725) \\
\hline \multirow[t]{2}{*}{ Gdp } & $1.373^{* * * *}$ & $1.576^{* * *}$ & $1.372^{* * *}$ \\
\hline & $(9.442)$ & (10.953) & (9.431) \\
\hline \multicolumn{4}{|c|}{ Control Variables } \\
\hline \multirow[t]{2}{*}{ Mob } & $3.546^{* * *}$ & $0.371^{* *}$ & $0.500^{* * *}$ \\
\hline & (9.167) & $(2.256)$ & (3.095) \\
\hline \multirow[t]{2}{*}{ Op } & $3.546^{* * *}$ & $3.492^{* * *}$ & $3.48^{* * * *}$ \\
\hline & (9.167) & (8.357) & (8.586) \\
\hline \multirow[t]{2}{*}{ Dis } & $-1.698^{* * *}$ & $-1.425^{* * *}$ & $-1.707^{* * *}$ \\
\hline & $(-6.005)$ & $(-4.979)$ & $(-6.02)$ \\
\hline \multirow[t]{2}{*}{ Exch } & $0.113^{* *}$ & $0.168^{* * * *}$ & $0.112^{* * * *}$ \\
\hline & $(2.535)$ & (3.774) & (2.514) \\
\hline \multirow[t]{2}{*}{ Inf } & $5.841^{* * * *}$ & $6.768^{* * * *}$ & $6.286^{* * *}$ \\
\hline & $(2.842)$ & (2.97) & $(2.84)$ \\
\hline \multirow[t]{2}{*}{ Reg } & $0.581^{* * * *}$ & $0.382^{* * *}$ & $0.578^{* * *}$ \\
\hline & $(5.254)$ & (3.587) & (5.215) \\
\hline$R^{2}$ & 0.491 & 0.458 & 0.491 \\
\hline Adjusted $R^{2}$ & 0.477 & 0.443 & 0.476 \\
\hline$N$ & 384 & 384 & 384 \\
\hline
\end{tabular}


Table 5. China’s ODI motivations, political risk, institutional distance and location choice (explained variable: ODI).

\begin{tabular}{|c|c|c|c|c|c|c|c|}
\hline Variable & Model 1 & Model 2 & Model 3 & Model 4 & Model 5 & Model 6 & Model 7 \\
\hline \multirow[t]{2}{*}{ Pr } & $1.167^{* * *}$ & $4.442^{* * *}$ & $11.763^{* * *}$ & & & & $0.939^{* * *}$ \\
\hline & (3.782) & $(4.229)$ & $(4.207)$ & & & & (4.293) \\
\hline \multirow[t]{2}{*}{ Id } & & & & $0.044^{* * *}$ & $-0.109^{* *}$ & $-0.35^{* * *}$ & 0.307 \\
\hline & & & & $(2.421)$ & $(-2.394)$ & $(-3.141)$ & (1.509) \\
\hline \multirow[t]{2}{*}{ Ore } & -10.368 & $5.531^{* * *}$ & $5.316^{* * *}$ & $11.816^{* * *}$ & $5.500^{* * *}$ & $5.290^{* * *}$ & $17.450^{*}$ \\
\hline & $(-1.278)$ & (6.086) & (5.920) & (5.506) & (5.448) & (5.369) & (1.857) \\
\hline \multirow[t]{2}{*}{ Pat } & $0.262^{* * * *}$ & $1.199^{* *}$ & $0.212^{* *}$ & $0.461^{* * *}$ & $0.61^{* * *}$ & $0.414^{* * *}$ & $1.151^{* *}$ \\
\hline & $(2.774)$ & (2.414) & $(2.256)$ & (5.018) & (5.631) & $(4.46)$ & (2.214) \\
\hline \multirow[t]{2}{*}{ GDP } & $1.38^{* * * *}$ & $1.284^{* * *}$ & $3.921^{* * *}$ & $1.584^{* * *}$ & $1.55^{* * *}$ & $1.148^{* * *}$ & $3.712^{* * *}$ \\
\hline & (9.521) & $(8.744)$ & $(5.600)$ & $(11.242)$ & $(10.866)$ & (5.873) & (4.336) \\
\hline \multirow[t]{2}{*}{$\mathrm{ORE} \times \operatorname{Pr}$} & $4.786^{*}$ & & & & & & -0.087 \\
\hline & (1.937) & & & & & & $(-0.427)$ \\
\hline \multirow[t]{2}{*}{ Pat $\times \operatorname{Pr}$} & & $-0.422^{* * *}$ & & & & & $-0.027^{* *}$ \\
\hline & & $(-2.98)$ & & & & & $(-2.183)$ \\
\hline \multirow[t]{2}{*}{$\mathrm{GDP} \times \operatorname{Pr}$} & & & $-0.822^{* * *}$ & & & & $-0.083^{* * *+}$ \\
\hline & & & $(-3.717)$ & & & & $(-3.660)$ \\
\hline \multirow[t]{2}{*}{ ORE × Id } & & & & $-0.403^{* * *}$ & & & $-0.574^{* *}$ \\
\hline & & & & $(-3.693)$ & & & $(-2.570)$ \\
\hline \multirow[t]{2}{*}{ Pat $\times$ Id } & & & & & $0.016^{* * *}$ & & 0.014 \\
\hline & & & & & $(2.875)$ & & $(0.961)$ \\
\hline \multirow[t]{2}{*}{$\mathrm{GDP} \times \mathrm{Id}$} & & & & & & $0.028^{* * *}$ & -0.024 \\
\hline & & & & & & (3.295) & $(-1.095)$ \\
\hline \multicolumn{8}{|c|}{ Control variables } \\
\hline \multirow[t]{2}{*}{ Mob } & $3.557^{* * *}$ & $0.579^{* * *}$ & $0.631^{* * *}$ & $0.383^{* *}$ & $0.396^{* *}$ & $0.432^{* * *}$ & $0.803^{* * *}$ \\
\hline & (9.229) & (3.592) & (3.902) & (2.373) & $(2.422)$ & $(2.630)$ & (5.074) \\
\hline \multirow[t]{2}{*}{ Op } & $3.557^{* * *}$ & $3.924^{* * *}$ & $3.703^{* * *}$ & $2.955^{* * *}$ & $3.610^{* * *}$ & $3.353^{* * *}$ & $2.931^{* * *}$ \\
\hline & (9.229) & (9.73) & (9.677) & (6.248) & (7.143) & $(7.007)$ & (6.007) \\
\hline \multirow[t]{2}{*}{ Dis } & $-1.755^{* * *}$ & $-1.529^{* * *}$ & $-1.605^{* * *}$ & $-1.462^{* * *}$ & $-1.363^{* * *}$ & $-1.367^{* * *}$ & $-1.708^{* * *}$ \\
\hline & $(-6.197)$ & $(-5.357)$ & $(-5.750)$ & $(-5.145)$ & $(-4.77)$ & $(-4.805)$ & $(-6.026)$ \\
\hline \multirow[t]{2}{*}{ Exch } & $0.127^{* * *}$ & $0.123^{* * *}$ & $0.134^{* * *}$ & $0.213^{* * *}$ & $0.176^{* * *}$ & $0.183^{* * *}$ & $0.180^{* * *}$ \\
\hline & $(2.831)$ & (2.79) & (3.026) & (4.728) & (3.984) & (4.149) & (4.075) \\
\hline \multirow[t]{2}{*}{ Inf } & $6.303^{* * *}$ & $6.995^{* * *}$ & $6.931^{* * * *}$ & $9.345^{* * *}$ & $8.777^{* * *}$ & $8.366^{* * *}$ & $9.558^{* * *}$ \\
\hline & (3.057) & (3.379) & (3.394) & (4.296) & $(4.024)$ & (3.850) & (4.589) \\
\hline \multirow[t]{2}{*}{ Reg } & $0.626^{* * *}$ & $0.528^{* * *}$ & $0.546^{* * *}$ & $0.367^{* * *}$ & $0.298^{* * *}$ & $0.286^{* * *}$ & $0.550^{* * *}$ \\
\hline & (5.56) & $(4.763)$ & $(5.005)$ & (3.231) & (2.618) & $(2.518)$ & (4.803) \\
\hline$R^{2}$ & 0.496 & 0.503 & 0.509 & 0.476 & 0.468 & 0.472 & 0.558 \\
\hline Adjusted $R^{2}$ & 0.481 & 0.488 & 0.494 & 0.461 & 0.453 & 0.456 & 0.538 \\
\hline$N$ & 384 & 384 & 384 & 384 & 384 & 384 & 384 \\
\hline
\end{tabular}

Third, the motivations of China's ODI MNEs include market-seeking, strategic asset-seeking and resourceseeking; resource-seeking investment is the strongest motivation. Fourth, for Chinese resource-seeking foreign investment, MNEs tend to invest in countries with high political risk and short institutional distance. For strategic asset-seeking foreign investment, MNEs tend to avoid countries with high political risk and short institutional distance. For market-seeking foreign investment, MNEs tend to avoid countries with high political risk and short institutional distance.

According to Model 1 in Table 5, political risk works as a positive moderator of the relationship between resource-seeking motivation and ODI. Stated differently, Chinese MNEs with high resource-seeking motivation tend to invest more in countries with both abundant resources and high political risk. One reason may be that 
most of the investors with high resource-seeking motivation are state-owned large- and medium-sized enterprises, which would ignore the political risk of the host country in favor of a more global development strategy for the country. According to Model 4 in Table 5, institutional distance is as a negative moderator of the relationship between resource-seeking motivation and ODI. That means Chinese MNEs with high resource-seeking motivation tend to invest more in countries with both abundant resources and similar institutional conditions. The main reason might be that the Chinese government may use ODI as a method for facilitating the realization of a strategic political objective. As a result, many firms engaging in ODI were encouraged to invest in countries with similar institutional conditions, i.e., a short institutional distance and high political risk (as most of these countries are developing countries with under-developed institutions and high political risk).

According to Model 2 and 5 in Table 5, political risk is a negative moderator of the relationship between strategic asset motivation and ODI while institutional distance works as a positive moderator. In other words, Chinese MNEs with high strategic asset motivation tend to avoid politically risky host countries and are inclined to select countries with institutional factors that are different from China's. MNEs high in strategic asset motivation engage in ODI mainly to purchase advanced technology, brands and fame, as well as capacity of management, which means that they would emphasize long-run profit rather than the short-term returns of ODI. Hence, political risk, which threatens the long-run profit of MNEs, would be a factor they would definitely avoid. Moreover, compared to developing countries, there are more advanced technologies and experienced managers in developed countries, which have larger institutional distances. Finally, given the motivation for strategic assets, much ODI is invested in developed countries. This explains why institutional distance is a positive moderator of the relationship between strategic asset motivation and ODI.

According to Model 3 in Table 5, political risk works as a negative moderator of the relationship between market-seeking motivation and ODI; that is, MNEs high in market-seeking motivation tend to avoid the political risks of the host country. Most of these MNEs are profit-pushing with profit maximization as their ODI goal. They avoid the political risk of the host countries for several reasons. First, political risk is bad for steady business operation. Furthermore, contrary to MNEs high in resources-seeking motivation, most of these MNEs may not get government support (such as financial support, policy support and administration compensation) to counteract the potential losses due to risk. Moreover, most ODI with strong market-seeking motivation is invested in developed countries, which have a low political risk. Two thirds of the wealth worldwide is distributed in developed countries, which have high per capita incomes and large market capacities. This fact also explains why institutional distance is a positive moderator of the relationship between market-seeking motivation and ODI in Model 6 in Table 5.

\section{Conclusions}

Since reforms opened up China's economy, exports and foreign direct investment, as two main patterns of internationalization, have promoted economic growth China and increased per capita income. The official "Go Global” policy was announced in 1999, and overseas investment was officially described as one of the FiveYear Plan's main objectives in 2001. Since then, China has integrated rapidly with the world economy by increasing its foreign investment linkages with other countries. In 2012, China was the third largest investor among all countries, up from fifth in 2011, with 179 countries and districts receiving China's ODI. Thus, ODI is crucial to the health of the Chinese economy.

This paper analyzes the effects of resources factors and institutional factors on China's ODI and establishes an analytic framework for the study of the interaction effects of location choice, foreign investment motivations, political risk, and institutional distance. This paper contributes to the development and improvement of the institution-based and resource-based FDI theory and enriches the background theory for Chinese foreign investment.

With a sample of ODI data for 48 countries and districts from the year 2003 to 2010, this paper applies multiple regression equations to develop an analysis of the effect of China's ODI motivations, political risk and institutional distance on location choice. First, both political risk and institutional distance exert significant influence on China's ODI. Generally, China's ODI MNEs are inclined to invest in countries with high political risk and short institutional distance. Second, we find that there are various motivations for China's ODI location choice, namely, resource-seeking, strategic asset-seeking and market-seeking motivations. Third, multinational enterprises with different ODI motivations exhibit diverse location choices. For resource-seeking foreign in- 
vestment, MNEs tend to invest in countries with high political risk and short institutional distance; for strategic asset-seeking foreign investment, MNEs tend to avoid countries with high political risk and short institutional distance; and for market-seeking foreign investment, MNEs tend to avoid countries with high political risk and short institutional distance.

\section{References}

[1] Kelley, D., Coner, J.K. and Lyles, M.A. (2013) Chinese Foreign Direct Investment in the United States: Location Choice Determinants and Strategic Implications for the State of Indiana. Business Horizons, 56, 443. http://dx.doi.org/10.1016/j.bushor.2013.03.005

[2] Wang, D.T. and Chen, W.Y. (2014) Foreign Direct Investment, Institutional Development, and Environmental Externalities: Evidence from China. Journal of Environmental Management, 135, 81. http://dx.doi.org/10.1016/j.jenvman.2014.01.013

[3] Wang, S., Tong, T.W., Chen, G.L. and Kim, H. (2009) Expatriate Utilization and Foreign Direct Investment Performance: The Mediating Role of Knowledge Transfer. Journal of Management, 35, 1181-1206. http://dx.doi.org/10.1177/0149206308328511

[4] Yan, D.Y., Hong, J.J. and Ren, B. (2010) Determinants of outward Foreign Direct Investment by Chinese Enterprises: An Empirical Study from Institutional Perspective. Nankai Business Review International, 1, 237-253. http://dx.doi.org/10.1108/20408741011069188

[5] Gaur, A.S. and Lu, J.W. (2007) Ownership Strategies and Survival of Foreign Subsidiaries: Impacts of Institutional Distance and Experience. Journal of Management, 33, 84-110.http://dx.doi.org/10.1177/0149206306295203

[6] Miller, S.R. and Eden, L. (2006) Local Density and Foreign Subsidiary Performance. Academy of Management Journal, 49, 341-355. http://dx.doi.org/10.5465/AMJ.2006.20786081

[7] Xu, D. and Shenkar, O. (2002) Institutional Distance and The Multinational Enterprise. Academy of Management Review, 27, 608-618.

[8] Xu, D., Pan, Y. and Beamish, P.W. (2004) The Effect of Regulative and Normative Distances on MNE Ownership and Expatriate Strategies. Management International Review, 44, 285-307.

[9] Glambosky, M.C., Gleason, K.C. and Madura, J. (2010) Political Risk and Purchases of Privatized State-Owned Enterprises. Financial Review, 45, 873-889.http://dx.doi.org/10.1111/j.1540-6288.2010.00275.x

[10] Rottig, D. (2008) Institutional Distance, Social Capital, and the Performance of Foreign Acquisitions in the United States. Florida Atlantic University, Florida.

[11] Ram, M. and Pietro, N. (2003) Political Tradition, Political Risk and Foreign Direct Investment in Italy. Management International Review, 43, 247-265.

[12] Schneider, F. and Frey, B.F. (1985) Economic and Political Determinants of Foreign Direct Investment. World Development, 13, 161-175. http://dx.doi.org/10.1016/0305-750X(85)90002-6

[13] Busse, M. and Hefeker, C. (2007) Political Risk, Institutions and Foreign Direct Investment. European Journal of Political Economy, 23, 397-415. http://dx.doi.org/10.1016/j.ejpoleco.2006.02.003

[14] Sami, U., Zeeshan, H.S. and Parvez, A. (2012) Impact of Exchange Rate Volatility on Foreign Direct Investment: A Case Study of Pakistan. Pakistan Economic and Social Review, 50, 121-138.

[15] Liargovas, P.G, and Skandalis, K.S. (2012) Foreign Direct Investment and Trade Openness: The Case of Developing Economies. Social Indicators Research, 106, 323-331. http://dx.doi.org/10.1007/s11205-011-9806-9

[16] Liu, S., Lu, J. and Tao, Z. (2008) Spillovers of FDI on Indigenous Manufacturing Firms: A Perspective of Geographic Distance. China Economic Quarterly, 8, 115-127

[17] Khrawish, H.A. (2014) The Effect of Economic and Financial Risks on Foreign Direct Investment in Jordan: Multivariate Analysis. International Business Research, 7, 124-136. http://dx.doi.org/10.5539/ibr.v7n5p124

[18] Makino, S., Lau, C. and Yeh, R.S. (2002) Asset-Exploitation versus Asset-Seeking: Implications for Location Choice of Foreign Direct Investment from Newly Industrialized Economies. Journal of International Business Studies, 33, 403-421. http://dx.doi.org/10.1057/palgrave.jibs.8491024

[19] Krifa-Schneider, H. and Matei, I. (2010) Business Climate, Political Risk and FDI in Developing Countries: Evidence from Panel Data. International Journal of Economics and Finance, 2, 54-65.

[20] Arslana, A. and Larimoa, J. (2011) Greenfield Investments or Acquisitions: Impacts of Institutional Distance on Establishment Mode Choice of Multinational Enterprises in Emerging Economies. Journal of Global Marketing, 24, 345356. http://dx.doi.org/10.1080/08911762.2011.602323 
Scientific Research Publishing (SCIRP) is one of the largest Open Access journal publishers. It is currently publishing more than 200 open access, online, peer-reviewed journals covering a wide range of academic disciplines. SCIRP serves the worldwide academic communities and contributes to the progress and application of science with its publication.

Other selected journals from SCIRP are listed as below. Submit your manuscript to us via either submit@scirp.org or Online Submission Portal.
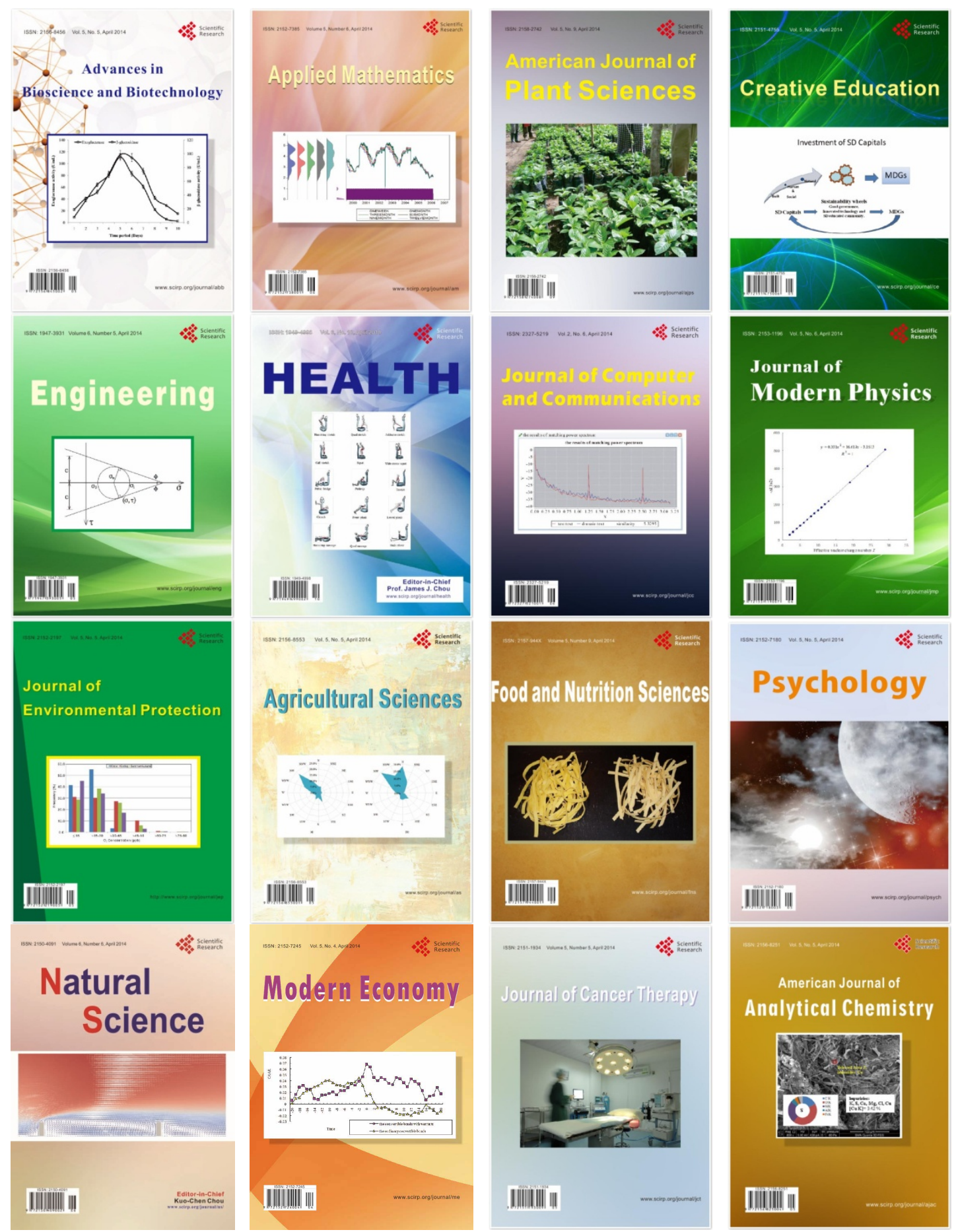